\title{
Wokół dyskusji o kondycji polskiego języka literackiego w XVII wieku
}

Wiek XVII oceniany był przez historyków języka polskiego bardzo skrajnie. Badacze początku XX wieku mówili o upadku bądź cofaniu się polszczyzny pod wpływem sytuacji polityczno-gospodarczej kraju i kontrreformacji. W drugiej połowie XX wieku spojrzenie zmieniło się diametralnie. Zwrócono uwagę na samą strukturę języka i zauważono, że czynniki zewnętrzne nie miały większego wpływu na kształtowanie się systemu językowego. Uznano zatem ten okres za równie prężny jak pozostałe, a nawet postępowy w stosunku do XVI wieku.

W dziejach państwa polskiego wiek XVII był czasem bardzo burzliwym. Kraj nękały rokosze, powstania kozackie i najazdy. Spowodowało to kryzys gospodarczo-ekonomiczny. Upadały rzemiosło i handel. Miasta na skutek oblężeń, głodu, epidemii i pożarów wyludniały się. W kwestiach religijnych skończył się okres tolerancji. Zwycięska kontrreformacja zmonopolizowała szkolnictwo i wprowadziła cenzurę. Wiele wybitnych dzieł renesansowych trafiło na indeks ksiąg zakazanych. Dochodziło nawet do wytaczania procesów autorom i palenia całych nakładów.

Sytuacja ta, zdaniem Aleksandra Brücknera, nie sprzyjała rozwojowi polskiego języka literackiego. Badacz XVII wiek nazywa czasem „obumarcia języka"1. Uzasadniając swoją ocenę, A. Brückner wskazuje przede wszystkim na rozprzestrzenianie się łaciny: ,Język literacki obumierał, ponieważ go nie zażywano wcale, a jeżeli po polsku mówiono, toć rugowano słowa polskie jako «niepolityczne»" $"$.

${ }^{1}$ A. Brückner, Powstanie i rozwój języka literackiego, w: idem, Poczqtki i rozwój języka polskiego, red. M. Karaś, Warszawa 1974, s. 93.

${ }^{2}$ Ibidem. 
Język był, jego zdaniem, w XVII wieku „zabijany makaronizmami”’. Polskie słownictwo bez potrzeby zastępowano terminologią łacińską. Badacz zwraca również uwagę na cofanie się prozy i ograniczenie właściwej twórczości literackiej do poezji. Szerzyła się natomiast literatura teologiczna, jednakże A. Brückner zaznacza, że już w latach trzydziestych nie stała na zbyt wysokim poziomie ${ }^{4}$.

Tadeusz Lehr-Spławiński także negatywnie postrzega wiek XVII. W pracy o pochodzeniu i rozwoju języka rozdział poświęcony drugiej połowie tego stulecia zatytułował: Powolny upadek języka literackiego ${ }^{5}$. Badacz uważa, że w okresie tym spadł poziom wyrobienia i kultury języka. Natomiast w samym systemie gramatycznym upadek, według T. Lehra-Spławińskiego, ujawnił się $\mathrm{w}$ archaizacji i prowincjonalizacji form fleksyjnych oraz w słownictwie. Należy jednak zaznaczyć, że spostrzega on również pozytywne symptomy:

Drobne zmiany w systemie odmian doprowadziły wówczas już język nasz do stanu bardzo mało się różniącego w zakresie budowy form od obecnego i przygotowały grunt do nowego okresu w jego rozwoju, okresu - można powiedzieć nowopolskiego, który rozpoczął się w ostatnich dziesiątkach w. XVIII, w dobie ponownego podniesienia się poziomu oświaty i kultury umysłowej w Polsce - za czym poszło odrodzenie piśmiennictwa i języka literackiego ${ }^{6}$.

Badacz nie zauważa znaczenia rozwoju fleksji dla języka literackiego. Zmiany, które zaszły w systemie, uznaje za drobne i stanowiące jedynie podłoże do odbudowy polszczyzny w wieku następnym, stulecie siedemnaste nadal postrzega jako czas upadku języka. Przyczyny zjawiska T. Lehr-Spławiński szuka w czynnikach wymienionych już przez A. Brücknera, to znaczy w sytuacji politycznej państwa i kontrreformacji. Negatywny wpływ na rozwój polszczyzny literackiej miało także, zdaniem badacza, szkolnictwo. W czasie kontrreformacji stojące na wysokim poziomie placówki innowiercze pozamykano, a szkoły jezuickie realizowały schematyczne nauczanie. W edukacji, sądach i sejmikach panowała łacina. Nie bez znaczenia dla rozwoju polszczyzny pozostawało też, jak dowodzi T. Lehr-Spławiński, zahamowanie ruchu publicystycznego, który dotąd współtworzył normę literacką. Jego roli nie mogło przejąć rozwijające się piśmiennictwo polemiczne o niewybrednym języku i stylu?

${ }^{3}$ Ibidem, s. 90.

${ }^{4}$ Ibidem, s. 89-93.

${ }^{5}$ T. Lehr-Spławiński, Powolny upadek języka literackiego (od połowy XVII do połowy XVIII w.), w: idem, Język polski. Pochodzenie, powstanie, rozwój, red. Z. Wojciechowski, wyd. 2, t. 2, Warszawa 1951, s. 286.

${ }^{6}$ Ibidem, s. 296.

${ }^{7}$ Ibidem, s. 286-305. 
Podobną opinię na temat drugiej połowy XVII wieku wygłosił Stanisław Słoński. Jego zdaniem polski język literacki, który ustalił się w dobie renesansu, upadł wraz z upadkiem literatury: „Druga połowa wieku XVII i wiek XVIII wraz z upadkiem literatury przynosi upadek języka, zwłaszcza w prozie"8. Wymienione przez badacza czynniki sprawcze pokrywają się z tymi, o których mówili A. Brückner i T. Lehr-Spławiński. Jednakże S. Słoński podjął się dodatkowo oceny systemu gramatycznego XVII wieku. Zdaniem badacza struktura języka literackiego nie różniła się zasadniczo od stanu dzisiejszego. W zakresie pisowni wiek XVII czerpał ze zdobyczy poprzedniej epoki, sam nic nie wnosił. Natomiast w ortografii panowało, według S. Słońskiego, całkowite zamieszanie i dowolność ${ }^{9}$. W ocenie tej razi powierzchowność, z jaką badacz potraktował system gramatyczny. S. Słoński zauważył tylko zewnętrzne cechy języka XVII wieku i mylnie je zinterpretował.

Omawiany okres negatywnie postrzega również Zenon Klemensiewicz. Badając sytuację polszczyzny doby średniopolskiej, zauważa, że poziom języka od lat czterdziestych XVII wieku do końca stulecia „obniża się na tle ogólnego cofania się życia polskiego pod znakiem sarmatyzmu" ${ }^{10}$. Większość spośród przyczyn regresu analizowanych przez Z. Klemensiewicza została już omówiona wcześniej. Z. Klemensiewicz zauważa dodatkowo wpływ literatury sowizdrzalskiej na język. Była to twórczość anonimowych, plebejskich literatów, pozbawionych wykształcenia i bezrobotnych. Wprowadzili oni do kulturalnej polszczyzny, o czym pisze badacz, wiele elementów języka potocznego i wulgaryzmów. Podkreśla również rolę ideologii sarmackiej w regresie języka i szerzeniu łaciny ${ }^{11}$.

Władysław Kuraszkiewicz nie mówi już o całościowym upadku języka w XVII wieku. Oddzielając w swej ocenie system gramatyczny od słownictwa, składni i frazeologii, spostrzega, że pierwszy uległ w XVII wieku dalszemu, naturalnemu i niezakłóconemu rozwojowi, podczas gdy słownictwo, składnia i frazeologia upadły razem z kulturą:

System gramatyczny polskiego języka literackiego urobiony w dziełach XVI w. trwa nadal, ulegając tylko powolnym zmianom naturalnego rozwoju. Natomiast ogólny upadek kultury polskiej drugiej połowy XVII w. zaznacza się w języku literackim szczególnie w zakresie słownictwa, składni i frazeologii ${ }^{12}$.

\footnotetext{
${ }^{8}$ S. Słoński, Historia języka polskiego w zarysie, Warszawa 1953, s. 131.

${ }^{9}$ Ibidem, s. 129-131.

${ }^{10}$ Z. Klemensiewicz, Historia języka polskiego, Warszawa 1974, s. 216.

${ }^{11}$ Ibidem, s. 215-284.

${ }^{12}$ W. Kuraszkiewicz, Tło społeczne rozwoju polskiego języka literackiego, w: Polski język literacki. Studia nad historiq i strukturq, wybór, oprac. W.R. Rzepka, B. Walczak, Warszawa-
} -Poznań 1986, s. 91. 
Według W. Kuraszkiewicza wyrażało się to w ubóstwie leksykalnym, przesadnej i sztucznej frazeologii, a zwłaszcza we wstawkach łacińskich. Bardzo ważnym procesem tego okresu było również, zdaniem badacza, zachwianie norm językowych: „W XVII i w XVIII wieku słabnie poczucie norm językowych, do języka literackiego wchodzą dialektyzmy"13. Główne tego przyczyny widzi autor w rozwoju ideologii sarmatyzmu, snobizmie i krótkowzroczności szlachty. Spowodowało to odcięcie stanu chłopskiego od edukacji i dobrodziejstw druku, a także upadek ekonomiczny miast i odsunięcie mieszczaństwa od polityczno-kulturalnego życia państwa. Jako czynnik równie ważny wskazuje W. Kuraszkiewicz kontrreformację. Podkreśla przede wszystkim ograniczenia cenzury, wpisanie najwybitniejszych dzieł XVI wieku na indeks ksiag zakazanych, prześladowanie innowierców, którzy mieli ogromny wpływ na kształtowanie się kultury i języka, a także zmonopolizowanie szkolnictwa przez jezuitów ${ }^{14}$.

W ocenie XVII wieku dokonanej przez A. Brücknera, T. Lehra-Spławińskiego, S. Słońskiego, Z. Klemensiewicza, a nawet W. Kuraszkiewicza pojawiają się mocno nacechowane określenia: upadek, regres, obumarcie języka. Badacze uzasadniali swoje stanowiska przede wszystkim widocznym w XVII stuleciu ubóstwem słownictwa, kalką łacińską w składni i rozprzestrzeniającymi się makaronizmami. Nieliczni poruszyli jeszcze kwestię grafii i ortografii, błędnie interpretując zasadę pisowni fonetycznej jako brak zasad. W konsekwencji bogactwo i wariantywność form postrzegali jako chaos i samowolę piszących. Badacze początku XX wieku opierali swoje opinie na tym, co w systemie językowym było bardziej widoczne, ale mniej ważne, nie zagłębiając się w samą strukturę języka. Szukając przyczyn upadku polszczyzny, postąpili podobnie. Nie brali pod uwagę procesów wewnętrznojęzykowych, które mogłyby prowadzić do regresu, lecz skupiali się na czynnikach pochodzących z zewnątrz języka.

W drugiej połowie XX wieku spojrzenie na omawiany okres ulega zmianie. Nowe światło na XVII wiek pierwsza rzuca Irena Bajerowa. Po prześledzeniu przemian językowych od 1675 do 1810 roku badaczka dochodzi do wniosku, że nie sposób mówić o upadku języka. Wiek XVIII i ostatnia ćwierć XVII stulecia jest „fazą zasadniczej, najcięższej i najrozleglejszej akcji porządkowania mocno rozczłonkowanego systemu przekształcającego się z wolna w całość prostszą, przejrzystszą i jednoznaczną"15. Jest to czas usuwania z języka form zbędnych, zwłaszcza pozostałości mieszania deklinacji i konsekwencji zaniku

13 Ibidem, s. 92.

14 Ibidem, s. 91-95.

15 I. Bajerowa, Kształtowanie się systemu polskiego języka literackiego w XVIII wieku, Wrocław 1964, s. 234. 
iloczasu, zatem okres intensywnych i niezwykle ważnych dla systemu językowego przemian. Natomiast czynniki zewnętrzne, o których tak wiele pisali poprzedni badacze, nie miały, według I. Bajerowej, decydującego wpływu na rozwój języka literackiego. Mogły w pewien sposób hamować tempo kształtowania kulturalnej polszczyzny, ale nie były w stanie zmienić kierunku tego procesu $^{16}$. Wydaje się, że można to odnieść również do wcześniejszych dziesięcioleci XVII stulecia.

Niczego nowego do oceny języka XVII wieku nie wnosi początkowo Stanisław Urbańczyk ${ }^{17}$. W swoich pierwszych pracach na temat stanu polszczyzny XVII wieku powiela poglądy A. Brücknera i Z. Klemensiewicza, uznając to stulecie, a zwłaszcza jego drugą połowę, za czas schyłkowy, w którym zaobserwować można „,cofnięcie się języka na wszystkich odcinkach”"18. Jednakże po dokładniejszym zbadaniu omawianego okresu S. Urbańczyk rehabilituje XVII wiek. Badacz zauważa bowiem, że do połowy stulecia instytucje służące językowi mogły sprawnie funkcjonować, rozwijało się szkolnictwo ${ }^{19}$, a dostęp do oświaty na najniższym poziomie został znacznie ułatwiony. Dzięki temu wychowankowie szkół utrzymywali do końca wieku wysoki poziom języka i literatury. W pierwszej połowie XVII wieku prężnie rozwijało się również drukarstwo. Niestety, na skutek potopu szwedzkiego, cenzury kościelnej, braku kapitalistów i odbiorców spadała liczba drukarń i druków, a to, co jeszcze wydawano, szybko zaczęło tracić na wartości. S. Urbańczyk wymienia również inne czynniki, które mogły negatywnie wpłynąć na rozwój polszczyzny. Zalicza do nich między innymi germanizację Śląska i Pomorza. Sprawa ta dotyczyła szczególnie chłopstwa. Problem stanowiło też rozmycie granic między dialektem kulturalnym ogólnopolskim a gwarami. Jednakże badacz zauważa, że ,zanim doszło do tych klęsk rozwój literatury i rozwój szkolnictwa umocnił pozycję kultywowanej odmiany języka"20. W XVII wieku musiało istnieć już jakieś poczucie normy, niedopuszczające elementów gwary do polszczyzny literackiej, równocześnie w języku nastąpiło w omawianym okresie wiele znaczących zmian, zarówno we fleksji i fonetyce, jak i w słownictwie. Kończąc swój wywód, S. Urbańczyk dochodzi do wniosku, że możliwości językowe

16 Ibidem, s. 6-9 i 232-239.

17 Mam tu na myśli pracę S. Urbańczyka, Periodyzacja dziejów polskiego języka literackiego, w: idem, Prace z dziejów języka polskiego, Wrocław 1979, s. 50-62.

18 Ibidem, s. 62.

19 Zdaniem S. Urbańczyka szkolnictwo, choć znacznie ucierpiało przez likwidację szkół innowierczych, zaczęło upadać dopiero na początku XVIII wieku (S. Urbańczyk, Sytuacja językowa w Polsce XVII wieku, w: Barok w polskiej kulturze, literaturze i języku, red. M. Stępień, S. Urbańczyk, Warszawa 1992, s. 237-249.

20 S. Urbańczyk, Sytuacja językowa w Polsce..., s. 244. 
w XVII wieku były duże, a ich wykorzystanie zależało tylko od sprawności twórcy i jego odbiorców:

Dzięki wysiłkom wielu pokoleń pisarzy powstał język literacki o wyraźnie zaaprobowanej gramatyce i słownictwu; dzięki powstaniu kilku centrów kulturalnych, w szczególności w Krakowie, dzięki oświacie i rozpowszechnieniu czytelnictwa powstał dialekt kulturalny [...]. Wykształciła się retoryka, styl naukowy. W miastach powstały odmiany środowiskowe, wyróżniające się obecnością swoistego słownika. Pisarze otrzymali więc środki językowe, które mogli wyzyskać zależnie od swojego talentu, od wykształcenia, od środowiska, dla którego pisali ${ }^{21}$.

Badacz zauważa również potrzebę dalszych szczegółowych studiów nad omawianym okresem i ostro krytykuje jego ocenianie na podstawie „dobranych tendencyjnie zwyrodniałych tekstów"22.

Z opinią badaczy początku XX wieku polemizuje także Halina Wiśniewska. We wstępie do Kulturalnej polszczyzny XVII wieku ${ }^{23}$ reinterpretuje wpływ wydarzeń polityczno-gospodarczych i religijnych na sytuację języka literackiego. Autorka ukazuje pozytywne skutki kontrreformacji. Uważa, że dominacja łaciny i usuwanie języka polskiego ze szkół paradoksalnie korzystnie wpłynęło na świadomość językową uczniów, ponieważ pojawianie się w podręcznikach do łaciny polskich egzemplów i tłumaczeń obcych prac, a także po polsku napisane gramatyki języka łacińskiego dla najmłodszych uczniów wspomagały tworzenie się normy języka polskiego. Powodowały również wzrost dbałości o ojczysty język. Ponadto autorka dowodzi, że dzięki jezuitom społeczeństwo było lepiej wyedukowane. Dotyczyło to nie tylko szlachty, ale także mieszczaństwa. Wzrosła liczba osób piśmiennych, a w związku z tym wzrosło również zapotrzebowanie na książki. W XVII wieku, mimo kryzysu ekonomicznego, powstało wiele oficyn, z których kilkanaście działało przez całe stulecie. Zdaniem H. Wiśniewskiej powiększyła się również liczba piszących. Popularne stało się pisanie pamiętników lub dzienników z podróży, wygłaszanie przemówień i tworzenie utworów okolicznościowych. Bogata literatura towarzyszyła także życiu politycznemu państwa. Za pomocą paszkwili pozbywano się przeciwników politycznych, a w drukach ulotnych wypowiadano na temat aktualnych wydarzeń. Porównując język XVI i XVII wieku, H. Wiśniewska dostrzega w XVII wieku ogromny postęp w położeniu języka literackiego: „Porównując stosunki językowe w wiekach XVI

21 Ibidem, s. 248-249.

22 Ibidem, s. 249.

${ }^{23}$ H. Wiśniewska, Kulturalna polszczyzna XVII wieku. Na przykładzie Zamościa, Lublin 1994. 
i XVII dostrzegamy jednak ogromny postęp w funkcjonowaniu polszczyzny, szczególnie w jej odmianie pisanej"24. Autorka podsumowuje w swej pracy to stulecie jako czas ,progresywnych zmian dla sytuacji, użytkowania i polerowania języka"25.

Podobne zdanie mają Danuta Ostaszewska i Mirosława Siuciak. We wstępie do Polszczyzny XVII wieku ${ }^{26}$ zapewniają, że w omawianym stuleciu system językowy był już w pełni uformowany i żadne czynniki polityczno-gospodarcze nie były w stanie go naruszyć:

Polszczyzna stanowi w XVII wieku dojrzały system - z wyraźnie wyodrębnioną odmianą ogólną, funkcjonującą zarówno na płaszczyźnie mówionej, jak i pisanej. Zdecydowała o tym zwłaszcza dbałość o poziom języka w pierwszej połowie tego stulecia. Następne półwiecza, kiedy sytuacja zewnętrzna staje się niekorzystna dla funkcjonowania języka polskiego, odziedziczyły więc ukształtowany już stan ogólnej polszczyzny literackiej, która wyraźnie odróżniała się od gwar. Stabilizacji owej nie były już w stanie naruszyć późniejsze klęski²7.

Jednakże o czynnikach zewnętrznych nie należy, według badaczek, zapominać, ponieważ miały one wpływ na tempo rozwoju języka literackiego. W XVII wieku spowalniane były przede wszystkim procesy syntaktyczne. Dla pozostałych poziomów języka, czego dowodzą autorzy Polszczyzny, XVII stulecie było okresem przełomowym. Najwięcej zmian zaobserwować można $\mathrm{w}$ systemie fleksyjnym. Wiele zjawisk wygasa w omawianym stuleciu, inne nasilają się bądź dopiero rozpoczynają ${ }^{28}$.

Według Alicji Pihan-Kijasowej owa ciagłość procesów świadczy o tym, że wiek XVII był dla rozwoju języka literackiego kolejnym, zwyczajnym etapem. Badaczka w artykule Literacka polszczyzna wielkopolska XVII wieku a język Samuela ze Skrzypny Twardowskiego zauważa, że na początku stulecia trwały jeszcze wpływy szesnastowieczne, natomiast w późniejszym czasie można wprawdzie zaobserwować pewne rozmycie normy, ale proces kształtowania się polszczyzny nie został zachwiany ${ }^{29}$.

Po prześledzeniu stanu badań widać, jak od początku XX wieku do początku wieku XXI ewoluowało spojrzenie na język literacki XVII stulecia. Pierwsi

${ }^{24}$ Ibidem, s. 6.

${ }^{25}$ Ibidem, s. 5-10.

${ }^{26}$ Polszczyzna XVII wieku. Stan i przeobrażenia, red. D. Ostaszewska, Katowice 2002.

27 Ibidem, s. 18.

${ }^{28}$ Ibidem, s. 11-24 i 278-279.

29 A. Pihan-Kijasowa, Literacka polszczyzna wielkopolska XVII wieku a język Samuela ze Skrzypny Twardowskiego, w: Wielkopolski Maro. Samuel ze Skrzypny Twardowski i jego dzieto w wielkiej i małej ojczyźnie, red. K. Meller, J. Kowalski, Poznań 2002, s. 47-49. 
językoznawcy skupiali uwagę na szerzących się makaronizmach, ubogim słownictwie i grafii fonetycznej, którą interpretowali jako zamieszanie. W swych pracach wiele miejsca poświęcali również negatywnemu wpływowi wydarzeń politycznych, stanu gospodarczo-ekonomicznego kraju, kontrreformacji i ideologii sarmackiej. Od drugiej połowy XX wieku inaczej zaczęto oceniać omawiany okres. Po licznych badaniach szczegółowych dowiedziono, że język w XVII wieku podlegał ciagłemu i niezaburzonemu rozwojowi. Natomiast wpływ czynników zewnętrznych był ograniczony i nie zawsze negatywny.

Opowiadając się zasadniczo po stronie stanowiska prezentowanego między innymi przez I. Bajerową czy H. Wiśniewską, warto zgromadzić argumenty językowe wzmacniające tę tezę. Argumentami tymi są procesy językowe toczące się w XVII wieku, będące w różnych fazach zaawansowania. Niektóre z nich pojawiły się przed wiekiem XVII, a w tym stuleciu się finalizowały. Do najbardziej charakterystycznych należą: wyodrębnienie kategorii męskoosobowej, zanik liczby podwójnej, demorfologizacja rodzaju w celowniku i miejscowniku liczby mnogiej, ukształtowanie się form deklinacyjnych celownika liczby pojedynczej rodzaju męskiego, miejscownika liczby pojedynczej rodzaju męskiego, narzędnika liczby pojedynczej rodzaju nijakiego i celownika liczby mnogiej rodzaju żeńskiego. Niektóre z procesów zapoczątkowanych przed omawianym okresem trwają przez wiek XVII, aż do końca doby średniopolskiej, a nawet nowopolskiej ${ }^{30}$. Sa to: wkraczanie form dopełniacza do biernika męskich form osobowych liczby mnogiej, demorfologizacja rodzaju w narzędniku liczby mnogiej, kształtowanie się odmiany liczebników głównych, stabilizacja akcentu paroksytonicznego, ustalanie się nosówek. Rozpoczynają się w XVII wieku także nowe tendencje: nowa forma trybu rozkazującego czasowników, których rdzeń stanowi grupa spółgłoskowa, unifikacja form dopełniacza liczby pojedynczej rodzaju żeńskiego i zanikanie samogłosek pochylonych.

Niektóre z sygnalizowanych wyżej argumentów zaświadczających stan siedemnastowiecznej polszczyzny warto pokrótce, dla ilustracji problemu, przypomnieć.

\section{Ortografia}

Cechą szczególną siedemnastowiecznej pisowni jest jej charakter fonetyczny. W pisowni starano się oddać możliwie wiernie język mówiony. Dzięki temu $\mathrm{w}$ wielu tekstach siedemnastowiecznych widoczne są różnorakie procesy asymilacyjne, ale także elementy języka właściwe konkretnym regionom,

${ }^{30}$ Podział na doby według periodyzacji polskiego języka literackiego Z. Klemensiewicza, przedstawionej w Historii języka polskiego. 
a nawet osobom (na przykład mazurzenie niektórych obszarów). Procesy asymilacyjne widoczne w tekstach dzięki grafii fonetycznej to przede wszystkim upodobnienia spółgłosek pod względem dźwięczności. Bardzo często dochodzi do ubezdźwięcznienia przedrostka roz-. Rzadziej uwidacznia się asymilacja pod względem miejsca czy sposobu artykulacji. Dzięki grafii fonetycznej w wielu tekstach zaznacza się również proces redukcji grup spółgłoskowych w śródgłosie, a niekiedy także w wygłosie ${ }^{31}$. Zasada fonetyczna popierana była przez wielki autorytet tamtych czasów - gramatyka Grzegorza Knapiusza. Przedkładał on ten rodzaj zapisu nad istniejącą równolegle grafię etymologiczną, ukazującą zależność między podstawą a formą pochodną ${ }^{32}$. Jednakże sam często odstępował od sformułowanej przez siebie zasady. Powodem niekonsekwencji był przede wszystkim brak znajomości fonetycznej wartości wyrazu. G. Knapiusz z pewnością zauważał, że pisownia fonetyczna oddala derywat czy formę zależną od podstawowej, często czyniąc przez to wyraz niezrozumiałym. W takich sytuacjach świadomie rezygnował z preferowanego przez siebie zapisu, na rzecz pisowni etymologicznej. Kolejnym powodem pojawiania się odstępstw w Thesaurusie mogło być także liczenie się siedemnastowiecznego gramatyka $\mathrm{z}$ tradycją ortograficzną ${ }^{33}$. W konsekwencji w pisowni panowała duża wariantywnośćc ${ }^{34}$.

Wiek XVII wprowadza do techniki pisarskiej również wiele uproszczeń. W omawianym okresie kończy się oznaczanie samogłosek pochylonych za pomocą znaku diakrytycznego. W XVI wieku samogłoski jasne $e$ i $o$ zapisywano jako $e, o$, natomiast pochylone $\dot{e}$ i $\dot{o}$ zapisywano ze znakiem diakrytycznym: $e ́, o ́$. Z samogłoską $a$ było na ogół odwrotnie: å pochylone zapisywane było jako $a$, zaś $a$ jasne miało znak diakrytyczny: $a ́$ lub zapisywane było bez tego znaku: $a$. W wieku XVII zwyczaj graficznego odróżniania samogłosek pochylonych i jasnych przestrzegany był wyjątkowo bądź wcale ${ }^{35}$. Szczególnie

31 A. Pihan-Kijasowa, Literacka polszczyzna kresów pótnocno-wschodnich XVII wieku. Fonetyka, Poznań 1999, s. 51-52.

32 Polszczyzna XVII wieku..., s. 37-38; zob. też I. Bajerowa, A. Wieczorkowa, Uwagi o pisowni polskich druków XVII-wiecznych, w: Studia historycznojęzykowe, red. I. Bajerowa, Katowice 1989, Prace Językoznawcze, t. XVII, s. 9-22.

33 J. Puzynina, ,Thesaurus” Grzegorza Knapiusza. Siedemnastowieczny warsztat pracy nad językiem polskim, Wrocław 1961, Prace Językoznawcze 29, s. 96-97.

34 Pisze o tym A. Pihan-Kijasowa: „Ponieważ jednak obok zapisów fonetycznych te same wyrazy czy też kategorie wyrazów pisane są również zgodnie z etymologią, powoduje to, że w przejrzanych drukach mamy do czynienia z dużą wariantywnością ortografii nawet w obrębie tego samego tekstu" (A. Pihan-Kijasowa, Literacka polszczyzna kresów..., s. 50).

35 Z. Klemensiewicz, op.cit., s. 285-290; Z. Klemensiewicz, T. Lehr-Spławiński, S. Urbańczyk, Gramatyka historyczna języka polskiego, Warszawa 1965, s. 85-101; S. Rospond, Gramatyka historyczna języka polskiego, Warszawa 1979, s. 69-71; zob. też I. Bajerowa, A. Wieczorkowa, op.cit. 
dotyczyło to samogłosek $e$ i $o$, bowiem $a-\dot{a}$ zapisywano jeszcze zgodnie z szesnastowieczną tradycją.

Wiek XVII rezygnuje też powoli z podwójnego oznaczania palatalności spółgłosek $\dot{s}, z ́, c ́$ przed samogłoską. Obok odziedziczonego z wieku XVI zapisu śi, zi $i, c ́ i+V$ zaczynają się pojawiać formy wariantywne $s i, z i, c i+V$, na przykład pierścień zamiast pierśćień. Z rzadka w siedemnastowiecznych tekstach można również napotkać kropkę w miejscu kreski: Káznodżieyskę ${ }^{36}$. Ostatecznie podwójne oznaczanie miękkości tych spółgłosek kończy się w drugiej połowie XVIII wieku ${ }^{37}$.

Dodatkowo przestaje się kropkować $z \mathrm{~W}$ dwuznakach $c z$ i $r z$, co było powszechnym zwyczajem jeszcze w wieku $\mathrm{XVI}^{38}$.

\section{Fonetyka}

W XVII wieku następuje sporo zmian fonetycznych. Mają one duże znaczenie także dla procesów fleksyjnych. Przede wszystkim w XVII stuleciu rozpoczyna się proces zaniku samogłosek pochylonych. Pochylone $o$ zbliża się coraz bardziej w swej barwie do $u$ bądź wyrównuje z $o$ jasnym. Zaciera się także odrębność é pochylonego, które obniża się do e jasnego albo upodabnia do wysokiej samogłoski $i$. Zachwianiu ulega również fonologiczna i fonetyczna różnica między å pochylonym i $a$ jasnym. Główną tego przyczyną jest zanik iloczasu, wraz z którym przestało istnieć funkcyjne uzasadnienie samogłosek pochylonych. Od tego czasu samogłoski te istniały jedynie jako bezzasadny relikt. Drugą bardzo ważną przyczyną jest szybki rozwój języka literackiego w XVI i pierwszej połowie XVII wieku, który spowodował gwałtowne porządkowanie systemu językowego ${ }^{39}$. Pewne znaczenie może mieć też wpływ wymowy kresowej, której samogłoski pochylone nie były znane ${ }^{40}$.

Wiek XVII jest również czasem ostatecznego uznania akcentu paroksytonicznego. Średniowieczny akcent inicjalny na początkowej sylabie zaczyna zanikać już w XV wieku. Wypiera go powoli pojawiający się akcent na zgłosce przedostatniej. W wieku XVI akcent paroksytoniczny rozprzestrzenia się i sta-

\footnotetext{
${ }^{36}$ Przykłady podaję za I. Bajerową i A. Wieczorkową (op.cit., s. 14).

${ }^{37}$ I. Bajerowa, A. Wieczorkowa, op.cit., s. 13-14 i Polszczyzna XVII wieku..., s. 33-34 i 69.

${ }_{38}$ Polszczyzna XVII wieku..., s. 35.

${ }^{39}$ I. Bajerowa, O zaniku samogłosek pochylonych (poktosie dyskusji), Katowice 1978, s. 57-59.

${ }^{40}$ I. Bajerowa, w przeciwieństwie do K. Nitscha, J. Rozwadowskiego, T. Lehra-Spławińskiego, Z. Stiebera, S. Urbańczyka i Z. Klemensiewicza, nie uznaje wpływu wymowy kresowej za główną przyczynę zaniku samogłosek pochylonych (zwłaszcza pochylonego å). Zob. I. Bajerowa, O zaniku..., s. 13-16. Por. też S. Urbańczyk, Przyczyny zaniku samoglosek pochylonych w języku polskim, w: idem, Prace z dziejów języka polskiego, Wrocław 1979, s. 265-277.
} 
bilizuje, ale dopiero w XVII wieku staje się normą, poświadczoną w 1621 roku przez Knapiusza $^{41}$.

W wieku XVII zaczyna się załamywać żywe jeszcze w XVI wieku wymawianie wygłosowych $b, p, w, f$ w sposób miękki: $b^{\prime}, p^{\prime}, w^{\prime}$ i $f^{\prime}$. Dzieje się to najpierw sporadycznie i regionalnie, ale szybko tendencja ta rozprzestrzenia się i w następnym stuleciu proces się kończy ${ }^{42}$.

Innym procesem fonetycznym wieku XVII jest zmiana w sposobie artykulacji głoski $\ell$. Nastapiła ona na przełomie XVI i XVII wieku. Na skutek wyeliminowania $\mathrm{z}$ wymowy przedniojęzykowo-zębowego zwarcia powstaje tak zwane $t$, wałczone" wymawiane jak $u$. Sporadycznie trafiała się taka artykulacja już w wieku XV, a rozpowszechniła najbardziej w wiekach XIX i $X^{43}$. Świadczy o tym między innymi przestrzeganie przez Onufrego Kopczyńskiego przed wymową typu maso, sowa zamiast masło, słowa ${ }^{44}$. Przykład siedemnastowiecznego wałczenia można znaleźć w Peregrynacji Maćkowej w wyrazach typu: okoo // około, poutory // póttora ${ }^{45}$.

\section{Fleksja}

We fleksji jednym z najważniejszych procesów było kształtowanie się kategorii męskoosobowej. Proces ten rozpoczął się już w XV wieku. Wiek XVII dla mianownika liczby mnogiej odziedziczył dla rzeczowników żywotnych dawną końcówkę deklinacji o-tematowej: -i (-y po stwardniałej) i końcówkę deklinacji u-tematowej: -owie. Dla nieżywotnych - właściwą dawnemu biernikowi końcówkę -y $(-i)$. W XVII wieku nazwy zwierząt zaczęły przybierać końcówki charakterystyczne dla rzeczowników nieżywotnych. Na skutek tego procesu, a także ekspansji końcówki -owie, pojawiają się liczne formy wariantywne, typu: krucy // krukowie // kruki, lwi // lwowie // lwy, orłowie // orty, psi // psy $y^{46}$.

Biernik liczby mnogiej odziedziczył końcówki dawnych deklinacji tematowych: w pierwotnych rzeczownikach o- i u-tematowych końcówkę -y // -i po $k, g$, w jo-tematowych i n-tematowych -e, a na ich wzór końcówkę -e przy-

${ }^{41}$ Z. Klemensiewicz, op.cit., s. 292-293.

42 Ibidem, s. 295.

${ }^{43}$ Ibidem, s. 296; Z. Klemensiewicz, T. Lehr-Spławiński, S. Urbańczyk, op.cit., s. 151; S. Rospond, op.cit., s. 117 i Polszczyzna XVII wieku..., s. 35 i 70.

${ }^{44}$ I. Bajerowa, Polski język ogólny XIX wieku. Stan i ewolucja, t. 1: Ortografia, fonologia z fonetyka, morfologia, Katowice 1986, s. 141. S. 151 .

45 Przykłady podaję za: Z. Klemensiewicz, T. Lehr-Spławiński, S. Urbańczyk, op.cit.,

${ }^{46}$ Z. Klemensiewicz, op.cit., s. 297; S. Rospond, op.cit., s. 242-244 i Z. Klemensiewicz, T. Lehr-Spławiński, S. Urbańczyk, op.cit., s. 275-278; przykłady podaję za: Z. Klemensiewicz, T. Lehr-Spławiński, S. Urbańczyk, op.cit., s. 277. 
brały też rzeczowniki i-tematowe ${ }^{47}$. Powoli jednak rzeczowniki męskoosobowe zaczęły przyjmować formę dopełniacza w funkcji biernika. W rzeczownikach występujących z przydawką $d w u$ charakterystyczna dla dopełniacza liczby mnogiej końcówka -ów pojawiła się pod koniec XVI wieku. W wieku XVII, na skutek zaniku liczby podwójnej, zaczęła zdobywać przewagę ${ }^{48}$. Analogiczną sytuację zaobserwować można w wypadku bierników łączących się z przydawkami: trzech i czterech, w których proces rywalizacji końcówek zakończył się już przed 1575 rokiem $^{49}$. W pozostałych rzeczownikach męskoosobowych stan pierwotny trwał do ostatniej ćwierci XVI wieku, a w niektórych tekstach nawet do pierwszego dziesięciolecia XVII ${ }^{50}$. Następnie zaczęły przybierać końcówkę -ów i w szóstym dziesięcioleciu XVII wieku osiągnęły średnią rozwojową. Natomiast cały proces wyrównywania biernika sfinalizował dopiero wiek XVIII ${ }^{51}$.

Wiek XVII był także czasem unifikacji form celownika i miejscownika liczby mnogiej. W początkowych dziesięcioleciach omawianego stulecia końcówka -om, pochodząca z deklinacji o-tematowej, wypiera inne końcówki celownika. W tym okresie ostatecznie zanika należąca do deklinacji męskiej i nijakiej końcówka -em, a także należąca do deklinacji żeńskiej samogłoskowej końcówka -am, mimo że jeszcze w połowie XVI wieku miała znaczną przewagę nad -om. Wygasły również wariantywne końcówki: -ąm (pojawiła się w XVI wieku w rzeczownikach rodzaju żeńskiego i rodzaju męskiego na -a) i - $u m^{52}$ (wariant fonetyczny końcówki -om, powstały na skutek silnego zwężenia ó przed nosówką $\left.{ }^{53}\right)$.

${ }^{47}$ Z. Klemensiewicz, T. Lehr-Spławiński, S. Urbańczyk, op.cit., s. 281-282; S. Rospond, op.cit., s. 246-247.

${ }^{48}$ Początki tego procesu w liczbie podwójnej datuje się już na ostatnie lata XIV wieku: na wzór wcześniejszych przemian w liczbie pojedynczej w rzeczownikach dualnych w miejscu pierwotnej końcówki - $a$ zaczęła pojawiać się dopełniaczowa końcówka - $u$, a następnie zaczerpnięta z rzeczowników spluralizowanych -ów, co miało ogromny wpływ na kształtowanie się nowej formy biernika męskoosobowego liczby mnogiej. Zob. W.R. Rzepka, Dopetniacz w funkcji biernika męskich form osobowych w liczbie mnogiej w polszczyźnie XVII w., Wrocław 1975, s. $50-52$.

${ }^{49}$ W.R. Rzepka, Dopetniacz w funkcji biernika..., s. 52.

50 W.R. Rzepka pisze, że Roczne dzieje kościelne Skargi z 1603 roku i Officina ferraria W. Roździeńskiego z 1612 roku, które utrzymują jeszcze dla rzeczowników męskoosobowych starą końcówkę biernika (Dopetniacz w funkcji biernika..., s. 54).

${ }^{51}$ W XVIII wieku zakończył się proces w zakresie źródeł drukowanych, w przypadku rękopisów do zakończenia procesu doszło jeszcze w wieku XVII, W.R. Rzepka, Dopetniacz w funkcji biernika..., s. 48.

${ }^{52}$ Wariant ten powstał na przełomie XIV i XV wieku, występował przede wszystkim w rzeczownikach rodzaju męskiego, rzadziej nijakiego, a tylko wyjątkowo w rodzaju żeńskim, W.R. Rzepka, Demorfologizacja rodzaju w liczbie mnogiej rzeczowników w polszczyźnie XVI-XVII wieku, Poznań 1985, s. 47.

${ }^{53}$ Ibidem, s. 36-44. 
W połowie XVII wieku zakończył się także proces normalizacji miejscownika. Z trzech aktywnych końcówek: charakterystycznej dla rodzaju męskiego i nijakiego -ech, nowego tworu -och, który pojawił się jeszcze w epoce przedpiśmiennej, i końcówki -ach, pochodzącej z odmiany żeńskiej samogłoskowej, przetrwała końcówka -ach, skutecznie rugując dwie pozostałe. Nieliczne formy, zawierające jeszcze w drugiej połowie XVII wieku końcówkę -ech lub -och, to naturalne resztki procesu ${ }^{54}$.

Proces demorfologizacji dotyczył również narzędnika, jednakże w tym wypadku trwał dłużej od pozostałych i jeszcze w XVII wieku nie został zakończony. Charakterystyczna obecnie dla narzędnika końcówka -ami ${ }^{55}$ pod koniec XVII stulecia w rzeczownikach nijakich nie osiagnęła średniej rozwojowej, wciąż walcząc z formami zakończonymi na $-y(-i)$. Do końca XVII wieku trwają z $-y(-i)$ również najodporniejsze rzeczowniki rodzaju męskiego ${ }^{56}$. Do załamania się tych form dochodzi dopiero w pierwszych dziesięcioleciach XVIII wieku. W XVII wieku, obok wyżej wymienionych, żywotne były w narzędniku jeszcze końcówki: -mi, odziedziczona z prasłowiańszczyzny i do dziś występująca w nielicznych rzeczownikach, i -oma, przejęta z liczby podwójnej. Ostatnia nie przetrwała pierwszej ćwierci XVII stulecia ${ }^{57}$.

Przełomowy proces dokonał się także w dopełniaczu liczby pojedynczej odmiany żeńskiej. Do XVII wieku dotrwały formy dopełniacza rodzaju żeńskiego odmiany samogłoskowej odziedziczone jeszcze z prasłowiańszczyzny. W zakresie tematów twardych przybierały końcówkę -y (-i po $k, g)$, natomiast $\mathrm{w}$ tematach miękkich -e powstałe z pierwotnego -ě. W XVII wieku rzeczowniki miękkotematowe przybrały również końcówkę -y // -i, upodabniając się do twardotematowych. Przez całe stulecie występowała także wariantywna końcówka - ej powstała albo pod wpływem dopełniacza rodzaju żeńskiego deklinacji złożonej przymiotników, albo na skutek przejścia pochylonego $\dot{e} \mathrm{w} e j$.

54 Ibidem, s. 111-125.

55 Końcówka -ami wywodzi się z narzędnika liczby mnogiej rzeczowników żeńskich samogłoskowych, które dawniej należały do grupy rzeczowników -a- i -ja-tematowych. W rzeczownikach żeńskich spółgłoskowych końcówka ta była obecna od najdawniejszych czasów, w rzeczownikach męskich i nijakich zaczęła pojawiać się w wieku XVI, a zdaniem S. Rosponda już w XV (op.cit., s. 257). Zob. Z. Klemensiewicz, S. Urbańczyk, T. Lehr-Spławiński, op.cit., s. 283, 295 i 307; S. Rospond, op.cit., s. 248 i 257-258.

56 Najodporniejszymi rzeczownikami rodzaju męskiego były: czas i wiek, przybierały one w narzędniku formę: czasy i wieki, odnosiły się do kategorii czasu i pełniły funkcję peryfrastycznych synonimów przysłówków, co sprzyjało skostnieniu formy fleksyjnej; W.R. Rzepka, Demorfologizacja rodzaju..., s. 66.

57 Ibidem, s. 58-75. 
Forma ta pojawiała się już w najstarszych zabytkach i utrzymała się do końca $\mathrm{XVII}$ wieku ${ }^{58}$.

Na siedemnaste stulecie przypada również kontynuacja kształtowania się liczebników głównych. Proces ten był wieloetapowy i trwał ponad cztery wieki. Doba średniopolska była czasem przebudowy systemu fleksyjnego liczebników, do wielu zmian doszło zwłaszcza w obszarze kategorii liczby i rodzaju ${ }^{59}$. W odmianie liczebnika $d w a$ wiek XVII zaowocował powstaniem wariantywnych form mianownika i biernika rodzaju męskoosobowego. Obok tradycyjnego $d w a j$ w użyciu były formy przejęte z dopełniacza: $d w u$, dwóch, $d w u c h$. W celowniku pojawiał się obok odziedziczonej formy dwiema nowy twór $d$ wom albo $d$ wóm, sporadycznie z o pochylonym, utworzony pod wpływem celownika liczby mnogiej rzeczowników i form trzem, czterem. W narzędniku szerzyła się forma dwoma, powstała już w XV wieku. W deklinacji liczebnika trzy wiek XVII nie wniósł tak wiele. Zaczęto używać form dopełniacza w funkcji mianownika. Zaszły też zmiany w narzędniku. Obok odziedziczonej formy trzemi (ewentualnie jeszcze wariant z $\dot{e}$ pochylonym) lub trzymi pojawiała się forma trzema powstała na wzór $d$ wiema ${ }^{60}$. W liczebnikach od pięciu do dziewięciuset głównym procesem siedemnastowiecznym było szerzenie się form z $-u$. Na początku wieku XVI końcówka - $u$ była charakterystyczna dla dopełniacza i miejscownika liczebników dwu, dwudziestu i dwustu. W ciągu następnych stuleci rozpowszechniła się, obejmując wartości od pięciu do dziewięciuset i wychodząc równocześnie poza pierwotne dla niej przypadki. W konsekwencji w pierwszych latach XX wieku końcówka - $u$ występowała już we wszystkich przypadkach od mianownika po miejscownik. Proces ten był wieloetapowy. Ogromne znaczenie miały tutaj formy pośredniczące kilka i wiele. Odmieniały się one na początku XVI wieku według paradygmatu rzeczownikowego i stanowiły drugie źródło pochodzenia morfemu $-u$. Upowszechnienie końcówki - $u$ nastappiło dzięki zanikowi liczby podwójnej. Na skutek tego procesu $-u$ zatraciło funkcję wyrażania parzystości i stało się wyznacznikiem mnogości ${ }^{61}$.

W wieku XVII zmianom podlegała także koniugacja. W stuleciu tym rozpoczął się proces upodabniania w zakresie trybu rozkazującego. Czasowniki

${ }_{58}$ Z. Klemensiewicz, op.cit., s. 299; Z. Klemensiewicz, S. Urbańczyk i T. Lehr-Spławiński, op.cit., s. 288-289; S. Rospond, op.cit., s. 260-262. Zob. też Polszczyzna XVII wieku..., s. 99-100.

${ }_{59}$ M. Siuciak, Ksztaltowanie się kategorii gramatycznej liczebnika w języku polskim, Katowice 2008 , s. $49-50$.

${ }^{60}$ Z. Klemensiewicz, op.cit., s. 302-303; Z. Klemensiewicz, S. Urbańczyk, T. Lehr-Spławiński, op.cit., s. 338-353; S. Rospond, op.cit., s. 289-294. Zob. też W.R. Rzepka, Gen.-Acc. Pl męskich form osobowych liczebników głównych, nieokreślonych oraz rzeczowników, w: Dopetniacz w funkcji biernika..., s. 35-71.

${ }^{61}$ M. Siuciak, op.cit., s. 80-82. 
o rdzeniu zbudowanym z grupy spółgłoskowej, na przykład tni, klni, zetrzy, zaczęły przybierać postać z jota, na wzór czasowników typu: bij, myj. Równocześnie trafiał się nowy twór w rodzaju wyciagniej, spojrzej, wesprzej powstały na skutek upodobnienia do form: chciej, miej, siwiej itp. Warianty te zanikają w następnym stuleciu ${ }^{62}$.

Wiek XVII jest również czasem ostatecznego zaniku liczby podwójnej. Proces ten trwał od dawna ${ }^{63}$. W celowniku wypieranie dualu przez formy liczby mnogiej zakończyło się już przed drugą ćwiercią XVI wieku ${ }^{64}$. Wiek XVI uporał się także z liczbą podwójną w dopełniaczu. W narzędniku i miejscowniku końcówki pierwotne (w narzędniku -ama dla niektórych rzeczowników rodzaju żeńskiego ${ }^{65}$ i -oma dla rodzaju męskiego, nijakiego i pozostałych rzeczowników rodzaju żeńskiego, w miejscowniku - $u$ dla każdego z rodzajów) dłużej broniły się przed ekspansją liczby mnogiej. Formy pluralne pełną normalizację osiagnęły w tych przypadkach między pierwszą a trzecią ćwiercią XVII stulecia ${ }^{66}$. Najdłużej, bo przez cały wiek XVII, stare formy liczby podwójnej utrzymywały się w mianowniku i bierniku. W męskich rzeczownikach miękkotematowych ${ }^{67}$ występujących w połączeniu z liczebnikiem $d w a^{68}$ i w żeńskich twardotematowych pierwotne formy były wypierane przez formy liczby mnogiej, które jednak nie przekroczyły w XVII wieku progu pełnej normalizacji. Żeńskie miękkotematowe rzeczowniki samogłoskowe ${ }^{69}$ formy

${ }^{62}$ Z. Klemensiewicz, op.cit., s. 303; Polszczyzna XVII wieku..., s. 164-166, stąd też zaczerpnęłam przykłady.

${ }_{63}$ J. Migdał i W.R. Rzepka w artykule: Wygasanie form dualnych rzeczowników w polszczyźnie XVI i XVII wieku, w: Język polski. Współczesność. Historia. II, red. W. Książek-Bryłowa, H. Duda, Lublin 2002, s. 141, za koniec żywotności liczby podwójnej przyjmują przełom doby staro- i średniopolskiej, Z. Klemensiewicz, S. Urbańczyk i T. Lehr-Spławiński (op.cit., s. 310) piszą o drugiej połowie XVI wieku.

${ }^{64}$ J. Migdał i W.R. Rzepka (op.cit., s. 161) piszą o zaniku form dualnych w celowniku jeszcze przed latami 1521-1535, nie wykluczajajednak sporadycznego pojawiania się tych form w innych, nieprzebadanych przez nich źródłach.

${ }^{65}$ Końcówka ta pierwotnie należała do odmiany żeńskiej samogłoskowej, przejęły ją niektóre rzeczowniki dualne żeńskie z odmiany spółgłoskowej. Pozostałe, podobnie jak większość rzeczowników rodzaju żeńskiego odmiany samogłoskowej, upodobniły formę do rodzaju męskiego z końcówką -oma, Z. Klemensiewicz, S. Urbańczyk, T. Lehr-Spławiński, op.cit., s. 311.

${ }^{66}$ J. Migdał i W.R. Rzepka granice pełnej normalizacji w narzędniku i miejscowniku wyznaczają na okres między latami 1610-1623 a 1643-1660, op.cit., s. 160.

${ }^{67} \mathrm{~W}$ dualu nieosobowe rzeczowniki twardotematowe rodzaju męskiego przejęly z deklinacji -u-tematowej końcówkę -y $(-i)$, od najdawniejszych czasów przybieraną przez nieosobowe rzeczowniki twardotematowe w liczbie mnogiej, J. Migdał, W.R. Rzepka, op.cit., s. 145.

${ }^{68}$ Według J. Migdał i W.R. Rzepki stanowią one 50\% użyć, op.cit., s. 160.

${ }^{69}$ Wiele miękkotematowych rzeczowników rodzaju żeńskiego odmiany spółgłoskowej przyjmowało w mianowniku i bierniku w XVI i XVII wieku końcówkę -i, charakterystyczną także dla liczby mnogiej, J. Migdał, W.R. Rzepka, op.cit., s. 149. 
pluralne utrzymywały przez XVII wiek w stanie niepełnej normalizacji obok form dualnych, natomiast wśród rzeczowników rodzaju nijakiego formy pluralne już w ostatniej ćwierci XVII stulecia osiagnęły pełną normalizację. Zatem przez wiek XVII w mianowniku i bierniku liczby podwójnej rywalizowały ze sobą końcówki dualne: dla rodzaju męskiego - $a$, żeńskiego rzeczowników twardotematowych $-e$, żeńskiego miękkotematowych samogłoskowych $-i / /-y$, nijakiego $-e^{70}$; i końcówki pluralne: dla rodzaju męskiego -e, żeńskiego twardotematowych $-i / /-y$, żeńskiego miękkotematowych samogłoskowych -e, nijakiego - $a$. W wieku XVII pojawiały się więc liczne formy wariantywne, typu: dwie głowie // dwie glowy, dwie świecy // dwie świece, dwie święcie // dwie $s^{w i e ̨ t a}{ }^{71}$. Liczba podwójna wyparta z języka ogólnego zachowała się w wielu gwarach. Tam oprócz tradycyjnych końcówek -wa i -ta powstał dodatkowo nowotwór $-m a^{72}$.

Początkowo wiek XVII niesłusznie postrzegany był przez takie autorytety, jak T. Lehr-Spławiński czy Z. Klemensiewicz jako okres zacofania i upadku, dzięki pracom I. Bajerowej został zrehabilitowany. Uznała ona ten wiek za czas dalszej, niczym niezaburzonej ewolucji języka i zakwestionowała wpływ czynników zewnętrznych na system. Późniejsze, bardziej szczegółowe badania doprowadziły innych językoznawców do podobnych wniosków. Ciagłość rozwoju języka w XVII wieku potwierdzają omówione w niniejszej pracy procesy. Ukazują one liczne próby upraszczania, porządkowania i doskonalenia systemu zachodzące w XVII wieku, takie jak demorfologizacja rodzaju gramatycznego w liczbie mnogiej czy zanikanie samogłosek pochylonych. O prężności języka świadczy również bogactwo form wariantywnych, będących wynikiem nakładania się starych i nowych tendencji, a często także rozwiązań, które się ostatecznie nie przyjęły. W świetle dzisiejszej, bardziej szczegółowej wiedzy o przebiegu procesów językowych w XVII wieku, należy okres ten uznać za równie ważny i postępowy jak pozostałe stulecia.

${ }^{70}$ Rodzaj nijaki w liczbie podwójnej, oprócz końcówki -e, charakterystycznej dla twardotematowych, odziedziczył miękkotematową końcówkę - $i / /-y$, jednak J. Migdał i W.R. Rzepka nie odnotowali żadnego rzeczownika liczby mnogiej rodzaju nijakiego z tą końcówką w tekstach z XVII wieku.

${ }^{71}$ Przykłady podaję za: J. Migdał, W.R. Rzepka, op.cit., s. 150 i 153.

72 Z. Klemensiewicz, op.cit., s. 304; Z. Klemensiewicz, S. Urbańczyk, T. Lehr-Spławiński, op.cit., s. 310-311. 


\section{Agnieszka Motyl}

\section{Around the Discussion about the Condition of the 17th-Century Polish Literary Language}

The article constitutes a compilation and recapitulation of the researchers' opinions on the condition of the 17th-century Polish literary language. In the beginning of the 20th century, the linguists such as Aleksander Brückner, Tadeusz Lehr-Spławiński or Zenon Klemensiewicz had a negative opinion on the 17th-century Polish language. In their works they mainly focused on external aspects of the language and pronounced the 17 th century as the time of its decline. This attitude altered diametrically under the influence of the studies conducted by Irena Bajerowa. She took a closer look at the structure of the 17th-century Polish and found out that the language was at that time subject to a continuous and uninterrupted development. The works of subsequent linguists confirmed and elaborated Bajerowa's conclusions. This thesis is also supported by the processes which began, lasted and ended in the 17th century. Among others, the processes include: the demorphologization of grammatical gender in the dative, locative and instrumental cases of the plural number, the separation of masculine category, the disappearance of dual number, the withdrawal of slanting vowels from the language and the formation of a new form of imperative mood of verbs. These processes show numerous attempts at introducing simplifications, regularities and improvements of the system and, as such, they are the manifestation of the permanent and undisturbed evolution of the 17 th-century Polish language. 
